\title{
The potential for a controlled human infection platform in Singapore
}

\author{
Shobana Balasingam ${ }^{1}$, BSc, MSc, Peter Horby $^{2}$, MBBS, PhD, Annelies Wilder-Smith ${ }^{3}$, MD, PhD
}

\begin{abstract}
For over 100 years, controlled human infection (CHI) studies have been performed to advance the understanding of the pathogenesis, treatment and prevention of infectious diseases. This methodology has seen a resurgence, as it offers an efficient model for selecting the most promising agents for further development from available candidates. $\mathrm{CHI}$ studies are utilised to bridge safety and immunogenicity testing and phase II/III efficacy studies. However, as this platform is not currently utilised in Asia, opportunities to study therapeutics and vaccines for infections that are important in Asia are missed. This review examines the regulatory differences for $\mathrm{CHI}$ studies between countries and summarises other regulatory differences in clinical trials as a whole. We found that the regulations that would apply to $\mathrm{CHI}$ studies in Singapore closely mirror those in the United Kingdom, and conclude that the regulatory and ethical guidelines in Singapore are compatible with the conduct of $\mathrm{CHI}$ studies.
\end{abstract}

Keywords: challenge studies, controlled human infections, ethics, experimental infections, GCP

\section{INTRODUCTION}

Controlled human infection (CHI) studies (also known as challenge studies) have a long and illustrious history of advancing the understanding of the pathogenesis, management and prevention of infectious diseases. (1) The fundamental scientific value of being able to control the nature and timing of infection and interventions in well-characterised human subjects remains unchanged, but it is now greatly enhanced by advances in immunology, functional genomics, microbiomics, pharmacogenetics, pharmacokinetics and pharmacodynamics. $\mathrm{CHI}$ studies have thus become a core methodology in modern infectious disease research.

Although $\mathrm{CHI}$ studies have been performed since the pre$1940{ }^{(2)}$ it is only in the last 10 to 15 years that the methodology has seen a resurgence, driven by the development of new therapeutics and vaccines against a range of organisms. This has in turn advanced the $\mathrm{CHI}$ model as a modern tool for attaining a deeper understanding of the pathogenesis of infection, as well as for drug and vaccine development. $\mathrm{CHI}$ studies offer an efficient model for the selection of the most promising agents from a diversity of available candidates for further product development, and are increasingly being utilised to efficiently bridge safety and immunogenicity testing and phase II/III efficacy studies. $\mathrm{CHI}$ studies not only allow efficacy data to be generated quickly, they also facilitate the identification of good immune correlates, the down-selection of vaccine candidates and early vaccine formulation decisions, thus avoiding unnecessary and costly large-scale trials. Indeed, the cost of a full set of trials (i.e. Phase I-IV) could be as high as $\$ 500$ million. ${ }^{(3)}$ While the $\mathrm{CHI}$ platform will not replace field studies, it can effectively screen the vaccines to take through to field studies.

\section{Procedure for a typical challenge study}

We use an influenza challenge to illustrate the procedure for a typical challenge study. A typical $\mathrm{CHI}$ study using influenza is usually carried out on healthy adult volunteers who are seronegative to the proposed challenge strain and who fulfill both the stringent inclusion and exclusion criteria. Successful volunteers are enrolled in the study. Depending on the type of study, they may be required to attend a number of screening and vaccination visits prior to the challenge. Volunteers are challenged by intranasal inoculation with a predefined concentration of a well-characterised attenuated virus produced under good manufacturing practices (GMP). Challenge typically occurs within two days of admission to the quarantine unit. Volunteers undergo quarantine for a period of up to 10 days (from admission to discharge), daily nasal washes (for viral load determination), blood withdrawal (for antibody testing, safety and immunology tests), measurement of temperature (up to four times a day), daily medical examinations by the study physician, spirometry (lung function determination), along with recording of their diary cards on a daily basis (for symptom scoring).

The quarantine unit is a controlled environment that allows for monitoring of any clinical signs of the given infection. As safety is paramount in any clinical study, volunteers are closely monitored by staff in the quarantine unit, which consists of study physicians and research nurses. Since influenza viruses naturally circulate in human populations and influenza challenge viruses are derived from naturally occurring influenza viruses, accidental release of a challenge influenza strain into the community is not likely to have any impact. Even so, precautionary measures are still taken to prevent the release of the challenge agent to the community. For instance, all staff working in the quarantine unit have to abide by a scrub-in and shower-out policy, and all items entering or leaving 
Table I. Challenge agents used in controlled human infection studies worldwide.(4-24)

\begin{tabular}{|c|c|c|c|c|c|c|}
\hline Pathogen & Year; country & Purpose & Agent grade & Agent source & Treatment & SAE \\
\hline \multirow[t]{7}{*}{ Influenza ${ }^{(4-10)}$} & 1994; US & $\begin{array}{l}\text { Efficacy of cold adapted } \\
\text { Influenza virus }\end{array}$ & NS & PRI/DynCorp & Oseltamivir & None known \\
\hline & 1998; US & Cytokine response & NS & NS & NS & None \\
\hline & 1999; US & Vaccine efficacy & NS & DynCorp & NS & None \\
\hline & 2000; US & Vaccine efficacy & NS & NS & NS & None \\
\hline & 2009; UK & Vaccine efficacy & NS & RVL & Oseltamivir & None \\
\hline & 2012; UK & Vaccine efficacy & GMP & NS & Oseltamivir & None \\
\hline & 2012; UK & $\mathrm{T}$ cell response evaluation & GMP & GSK & NS & None \\
\hline $\begin{array}{l}\text { Influenza, } \\
\text { HRV39, RSV(11) }\end{array}$ & 2009; UK & Gene switching & GMP & $\begin{array}{l}\text { Influenza: Baxter } \\
\text { BioScience, Vienna } \\
\text { HRV39: Charles River } \\
\text { RSV: MLS, USA }\end{array}$ & $\begin{array}{l}\text { Oseltamivir } \\
\text { (Influenza) }\end{array}$ & None \\
\hline $\begin{array}{l}\text { Malaria }{ }^{(12-16)} \\
\text { P. falciparum }\end{array}$ & $\begin{array}{l}\text { 2005; } \\
\text { Netherlands } \\
\text { 2005; UK } \\
\text { 2008; UK } \\
\text { 2009; US } \\
\text { 2011; UK }\end{array}$ & Vaccine efficacy & Lab grade & $\begin{array}{l}\text { Radboud University } \\
\text { Medical Centre, } \\
\text { Nijmegen, Netherlands(12) } \\
\text { Walter Reed Army } \\
\text { Institute of Research(16) } \\
\text { Information not } \\
\text { supplied(13-15) }\end{array}$ & $\begin{array}{l}\text { Riamet, }{ }^{(13,16)} \\
\text { chloroquine } \\
\end{array}$ & $\begin{array}{l}\text { Myocardial } \\
\text { infarction }{ }^{(12)}-\text { the } \\
\text { volunteer } \\
\text { recovered. Three } \\
\text { nonfatal SAEs in } \\
\text { the control group } \\
\text { were reported } \\
\text { in separate } \\
\text { subjects. }^{(15)} \\
\text { None }^{(13,14,16)}\end{array}$ \\
\hline $\begin{array}{l}\text { Respiratory } \\
\text { syncitial virus }^{(17,18)}\end{array}$ & 2010; UK & $\begin{array}{l}\text { Disease progression } \\
\text { antiviral therapy }\end{array}$ & GMP & $\begin{array}{l}\text { Bioreliance Inc, } \\
\text { Rockville, MD, USA }\end{array}$ & None & None \\
\hline Dengue $\mathrm{D}^{(19-21)}$ & 2008; US & Immune response to & GMP & Walter Reed Army & None & None \\
\hline DENV-1 \& DENV-3 & $\begin{array}{l}\text { 2011; US } \\
\text { 2013; US }\end{array}$ & $\begin{array}{l}\text { infection; diagnostic } \\
\text { development; vaccine } \\
\text { efficacy }\end{array}$ & & Institute of Research & & \\
\hline Norovirus $(22,23)$ & $\begin{array}{l}2008 \text { \& 2011; } \\
\text { US }\end{array}$ & $\begin{array}{l}\text { Disease progression; } \\
\text { efficacy of vaccine }\end{array}$ & $\begin{array}{l}\text { Non-GMP } \\
\text { (safety } \\
\text { tested) }\end{array}$ & $\mathrm{NIH}$ & None & $\begin{array}{l}\text { Two SAEs not } \\
\text { related to study } \\
\text { administration. }{ }^{(22)}\end{array}$ \\
\hline $\begin{array}{l}\text { Vibrio cholera }{ }^{(24)} \\
\text { (V. cholerae } 3008)\end{array}$ & 2005; Cuba & Efficacy of vaccine & Non-GMP & University of Maryland & None & None \\
\hline
\end{tabular}

GMP: Good Manufacturing Practice; GSK: GlaxoSmithKline; MLS: Meridien Life Sciences; NIH: National Institute of Health; NS: information not supplied; RVL: Retroscreen Virology; SAE: serious adverse events

the unit are decontaminated with $70 \%(\mathrm{v} / \mathrm{v})$ industrial methylated spirit/distilled water to minimise the risk of other viruses entering the unit or the challenge virus being released to the community. Volunteers are also given a course of antiviral medication prior to being released from the quarantine unit.

\section{Current CHI research worldwide}

In Europe and the United States (US), CHI studies are regularly performed using various viruses, bacteria and parasites. Table I shows a list of some of the challenge agents being used in $\mathrm{CHI}$ studies worldwide. ${ }^{(4-24)}$

Globally, the number of clinical trials conducted is on the rise and they are increasingly being conducted in less wealthy countries outside of the US and Europe, where the cost of running trials is substantially lower. ${ }^{(25)} \mathrm{CHI}$ studies, however, have yet to be conducted in modern Asia, and as such, Asian populations are under-represented in research that uses this platform. It is our view that there is a compelling case for the $\mathrm{CHI}$ methodology to be established locally, as Singapore is unrivalled in the region in terms of its infrastructure, technology, expertise and regulatory environment. These are the requisite qualities that would enable Singapore to fully and safely exploit the enormous potential of $\mathrm{CHI}$ studies and to become a world leader in this field. $\mathrm{CHI}$ studies require a robust regulatory environment in order to ensure the safety of the infected subjects, protect the subjects' autonomy, and safeguard the staff and general public from onward transmission of infection from the study subjects. Singapore, with its well-defined regulatory and ethical framework governed respectively by the Health Sciences Authority (HSA) and various ethics committees, is in an excellent position to initiate $\mathrm{CHI}$ studies.

In this article, we aim to review the ethical and regulatory requirements for conducting clinical trials in the US, Europe and Singapore, with particular reference to controlled human infections, in order to better understand the prerequisites necessary to establish $\mathrm{CHI}$ studies in Singapore.

\section{ETHICAL CONSIDERATIONS FOR CHI STUDIES}

The need for guidelines in $\mathrm{CHI}$ studies has arisen from unethical research conducted in the early 20th century and prior, including studies involving direct inoculation of infectious agents with neither the subject's consent nor any concern for the subject's wellbeing. A classic example of such unethical trials conducted on individuals who had not volunteered for experimentation is the medical 
research conducted during World War II involving the use of infectious agents (e.g. plague, malaria, typhoid), poisons and surgery on live patients. These 'trials' resulted in the death of thousands and were classified as war crimes after the War ended. In Singapore during the War, the Japanese established Unit 731, comprising eight divisions and a subunit known as the Oka Unit (9420), which specialised in plague and malaria. Division one of Unit 731, which concentrated on research with bubonic plague, cholera, anthrax, typhoid and tuberculosis using live human subjects, had access to a specially built 'research' prison that housed about 400 inmates. ${ }^{(26)}$ During the Nuremberg trials, these and other examples of criminal activity and medical murder masquerading as medical research were highlighted. (27) One such documented case involved an American, Dr Richard Strong, then head of the Philippine Biological Laboratory, who inoculated 24 inmates of Manila's Billibid Prison with a cholera vaccine that had been contaminated with plague organisms, which resulted in 13 deaths. ${ }^{(28)}$

The aforementioned cases and many others have resulted in stringent legislation and regulation surrounding clinical trials. As a result of the numerous Nuremberg trials, the recruitment of volunteers in present-day trials is vastly different from the involuntary recruitment of individuals in these cases. The Nuremberg Code, issued in 1947, was a direct outcome of these trials and contained several stringent principles for conducting research on humans, with an emphasis on voluntary participation and informed consent, which ultimately serves to protect volunteers in all clinical trials. ${ }^{(29)}$ The Nuremberg Code, in turn, led to the development of the Declaration of Helsinki by the World Medical Association in 1964, which set ethical guidelines for human research. ${ }^{(30)}$ The International Conference on Harmonisation $(\mathrm{ICH})$ subsequently used the Declaration of Helsinki as a basis for the development of the Good Clinical Practice (GCP) guidelines. ${ }^{(31)}$

The major difference between $\mathrm{CHI}$ studies and traditional clinical trials is the deliberate exposure of volunteer subjects to a pathogenic organism. In challenge studies, 'harm' - in the sense of deliberately seeking to infect a volunteer - is intended and not merely foreseen. Is this morally different from other types of accepted practices of clinical trial? In fact, most clinical trials involve some forms of risk to the participants since many licensed drugs have a known risk of adverse side effects, although at a frequency and severity deemed acceptable when compared to the benefits of the research. Phase I trials have the additional inherent risk of unknown adverse events, and there are no set criteria for acceptable adverse events rates.

The ethics of human challenge studies have been reviewed by several groups. ${ }^{(32-34)}$ Lynch concluded that "exposure to toxicity versus infection is not itself a morally relevant difference ${ }^{\prime \prime(33)}$ and thus, there should not be, in principle, any objection to human challenge studies. However, "the risks to the safety of participants (both of the enrolled subjects and the broader public) must not be greater than is acceptable in other forms of research". ${ }^{(35)}$ The above position is reflected in the acceptance of human challenge studies by the European Medicines Agency (formerly European Agency for the Evaluation of Medicinal Products, or EMEA), a European Union (EU) regulatory agency for the clinical evaluation of vaccines, ${ }^{(36)}$ as well as by the US Food and Drug Administration (FDA). ${ }^{(37)}$

$\mathrm{CHI}$ studies are generally low risk; the risks are evaluated and reduced such that the expected harm is as small as possible. ${ }^{(1)}$ Microbes used in the studies are well characterised, cause a self-limiting infection, and usually have a known treatment. Furthermore, volunteers are carefully prescreened for risk factors for severe illness and closely monitored for any adverse events.

\section{INTERNATIONAL CONFERENCE ON HARMONISATION OF GOOD CLINICAL PRACTICE (ICH GCP)}

The conduct of clinical trials is subject to GCP guidelines. $\mathrm{ICH}$ GCP is an international ethical and scientific quality standard for the conduct of clinical trials involving human volunteers. Governed by EMEA, the ICH GCP guidelines are updated and revised by the working group. These guidelines, developed based on the Declaration of Helsinki, provide a standard for the EU, Japan and the US, and took into consideration the national GCP guidelines of these three countries, as well as those of Australia, Canada and the World Health Organization (WHO). The purpose of the $\mathrm{ICH}$ is to ease the acceptance of data by the regulatory bodies in these jurisdictions. ${ }^{(38)}$

Interestingly, the $\mathrm{ICH}-\mathrm{GCP}$ guidelines do not include several requirements that are part of the Declaration of Helsinki. These include the requirement that the study design be publicly disclosed and the results published, restrictions on the use of placebo controls in developing countries, the disclosure of negative findings to the public, and access to posttrial treatment. This omission has caused some concern, as the FDA no longer follows the Declaration of Helsinki in all trials conducted outside the US, choosing instead to follow the ICH-GCP guidelines alone. There is a possibility that other regulators will follow suit, leading to ethical implications for trials conducted in low-income countries with vulnerable populations. ${ }^{(39)}$ To further compound this, the Declaration of Helsinki was recently revised to increase protection for vulnerable populations based on the premise that they are at a bigger risk of incurring more harm. ${ }^{(40)}$ There are inevitably vulnerable populations in all countries, including Singapore, who could be enticed into taking part in clinical trials for monetary reasons. Despite the importance of recruiting the required subject pool for clinical studies by means of monetary incentives, the onus is on those running the trials to ensure that vulnerable populations are not considered for participation. Volunteers must fully understand the study and agree to participate based on their comprehension of the study, and not solely for the reimbursement. $\mathrm{CHI}$ studies typically pay a heavy reimbursement to volunteers as compensation for undergoing the challenge and other procedures, for the many clinic visits, as well as for time away from family and friends during the quarantine period (which allows for a controlled environment and continual monitoring).

Countries such as Singapore, the UK and the US, unlike developing countries, have well-established volunteer recruitment guidelines, ethics committees and clinical trial experience, as well 
as stringent inclusion/exclusion criteria and effective government monitoring agencies such as the HSA, Medicines and Healthcare Products Regulatory Agency (MHRA) and FDA, to ensure that volunteers are not adversely treated.

Clinical trial activities in Europe are regulated by harmonised European legislation, of which the principal directives are the Clinical Trials Directive (2001/20/EC) of April 4, 2001 and the GCP Directive (2005/28/EC1) of April 8, 2005. Change is afoot, however, with the Clinical Trials Directive (2001/20/EC) being replaced with the new EU regulation (No 536/2014), which will be enforced from May 16, 2016. The major changes in the new Directive are: (a) For trials being conducted in multiple EU Member States, the Sponsor will submit one application to all Member States involved using the new EU portal system. There will be only one reporting Member State. This reporting Member State will inform the Sponsor, in 10 days, whether that application on review is valid; (b) The application is assessed in two parts by each Member State - the first is a scientific assessment and the second, a national assessment (e.g. the suitability of the study site); (c) Informed consent will be provided to the volunteer by a team member qualified to the law of the Member State and verification that the volunteer understood the information will be sought; (d) Member States must be informed of the start and end of the trial via the EU portal within 15 days; (e) Serious breaches of the protocol or the Regulation must be reported via the EU portal within 7 days of the breach; $(f)$ Member States must ensure there is provision for compensation to volunteers; and (g) A summary report of the data must be submitted within one year of the end of the trial regardless of the trial outcome. ${ }^{(41)}$ The Clinical Trials Directive, which sets out how clinical trials investigating the efficacy and safety of a medicinal product should be performed, was implemented as a law in the UK in 2004 and introduced to harmonise clinical trials across the EU with clear, transparent procedures. The directive requires clinical trials to be carried out in accordance with the GCP guidelines. The GCP Directive supplements the Clinical Trials Directive and supports the legal basis for requiring member states to comply with the principles and guidelines of the GCP, as set out in the ICH GCP guidelines. In the UK, all clinical research facilities are regularly inspected by the MHRA to ensure that they meet these standards. A clinical trial must also have ethical approval from a properly constituted research ethics committee to ensure that ethical standards are met and that volunteers are protected.

Similar to Europe and the US, clinical research activities in Singapore are subject to a regulatory and ethical framework regulated and approved by the HSA and Singapore Accreditation Council (SAC). The ethical evaluation is performed by an ethics committee. The Singapore Guidelines for Good Clinical Practice (SGGCP) was developed by the Health Products Regulation Group (HPRG), HSA. The Medicines (Clinical Trials) Regulations were reviewed and updated in April 1998, and implemented the SGGCP on August 1, 1998. ${ }^{(42)}$ The SGGCP, which was adapted from the ICH GCP, sets ethical and scientific standards for the conduct of clinical trials and assures that results obtained from clinical trials are credible.
Although the guidelines in the aforementioned countries are based on the principles of the ICH GCP, there are still differences and modifications present in each guideline to suit the requirements of each country. ${ }^{(31)}$ For the purpose of $\mathrm{CHI}$ studies, the similarities and differences of various ethical principles in Europe, the US and Singapore are summarised in Table I.

\section{DIFFERENCES IN REGULATORY REQUIREMENTS FOR CHI STUDIES}

The regulatory requirements for $\mathrm{CHI}$ studies vary according to countries. The major difference lies in the requirements for the challenge pathogen. These include differences in the level of release testing required as well as the requirements set by the regulatory agency for the challenge pathogen to be deemed suitable for use before subjects are challenged in a clinical trial.

For instance, FDA considers live organisms to be 'biologics'. A biologic is considered a 'drug' and hence, subject to regulation under federal law (section 351 of the Public Health Service Act and Food, Drug and Cosmetic Act). As such, the challenge organism must satisfy FDA regulations of safety, purity and potency. ${ }^{(43)}$ Challenge strains are, therefore, required to have undergone safety testing and detailed documentation of their provenance and manufacture. In addition the FDA has declared that an "Investigational New Drug Application (IND) is required for challenge studies in which live organisms (e.g., virus, bacteria, or fungi that is modified or wild-type) is administered to subjects to study the pathogenesis of disease or host response to the organism $^{\prime \prime}{ }^{(37)}$

This is not, however, the position of the European Economic Area (EEA), which considers the challenge agent as a NonInvestigational Medicinal Product (NIMP). ${ }^{(44)}$ This means that it does not fall within the rules for manufacturing of medicinal products, as set out in Title IV of Directive 2001/83/EC5, or the rules for manufacturing of IMPs, as set out in Article 13 of Directive 2001/20/EC, Article 9 of Commission Directive 2005/28/EC and Commission Directive 2003/94/EC.6. While NIMPs do not have a marketing authorisation in the EU, they have to be manufactured under GMP guidelines, such that they are as safe for subjects as an IMP would be. ${ }^{(4)}$ The challenge virus, once manufactured and having undergone safety testing and released by a Qualified Person, can then be used in a controlled infection trial. ${ }^{(45)}$ Trials such as dose ranging studies to determine the optimal dose of a challenge virus for use in an intervention study do not require MHRA notification or approval.

In Singapore, the challenge virus is not deemed a medicinal product, and therefore, a dose ranging study with just the challenge virus alone would not require HSA approval (information based on personal communication with the HSA). However, other requirements such as a Clinical Trial Certificate may be required, since any $\mathrm{CHI}$ study in Singapore is likely to be the first in Asia. As such, HSA's involvement in the first few $\mathrm{CHI}$ studies would be paramount. Table II lists some of the notable differences in the ICH GCP guidelines between the EU, the US and Singapore. ${ }^{(38,42,46-48)}$ 
Table II. Differences in the ICH GCP regulations among the EU, the US and Singapore.

\begin{tabular}{|c|c|c|c|}
\hline Regulation & EU & US & Singapore \\
\hline $\begin{array}{l}\text { Clinical trial } \\
\text { authorisation }\end{array}$ & $\begin{array}{l}\text { - One CA submission for each MS } \\
\text { - } 28 \text { countries }=28 \text { authorities }\end{array}$ & $\begin{array}{l}\text { - One regulatory authority at the } \\
\text { federal level (FDA) } \\
\text { - single submission = single } \\
\text { authorisation }\end{array}$ & $\begin{array}{l}\text { - One regulatory authority } \\
\text { - All clinical trials on medicinal products } \\
\text { conducted in Singapore require a CTC } \\
\text { from the Health Products Regulation } \\
\text { Group, HSA }\end{array}$ \\
\hline Protocol & $\begin{array}{l}\text { - Stand alone submission to the CA for } \\
\text { each protocol Review time frame for } \\
\text { the EC: } 60 \text { days maximum } \\
\text { - CTA is required to proceed } \\
\text { - No CTA is required for trials with } \\
\text { NIMPs } \\
\text { - Discussions are limited, with } \\
1 \text { opportunity to supply requested } \\
\text { information or application is rejected }\end{array}$ & $\begin{array}{l}\text { IND is required for studies involving } \\
\text { a live organism (virus, bacteria, } \\
\text { etc.) to be given to volunteers } \\
\text { - Review time frame is } 30 \text { days } \\
\text { - No official review } \\
\text { timeframe for subsequent } \\
\text { amendments (protocols) to the IND } \\
\text { - IND written approval is not } \\
\text { required to start a clinical trial; trial } \\
\text { may start } 30 \text { days after submission, } \\
\text { unless otherwise notified } \\
\text { Discussions with the FDA are not } \\
\text { limited }\end{array}$ & $\begin{array}{l}\text { - Stand alone submission } \\
\text { PIs must obtain both ethics and } \\
\text { regulatory approval before initiating a } \\
\text { study } \\
\text { - EC will review a proposed clinical trial } \\
\text { within } 30 \text { working days, discounting } \\
\text { waiting time } \\
\text { - No is CTC required for trials with NIMPs } \\
\text { - Discussions with the HSA are not limited }\end{array}$ \\
\hline $\begin{array}{l}\text { IMP } \\
\text { requirements }\end{array}$ & $\begin{array}{l}\text { - Label must comply with Annex } 13 \text { of } \\
\text { EU Directive } 2001 / 83 / E C \\
\text { - The language may vary between MS } \\
\text { - Sponsor is responsible for the } \\
\text { destruction of unused and/or } \\
\text { returned IMP } \\
\text { - Label requires expiry date }\end{array}$ & $\begin{array}{l}\text { - Label must be in English, except for } \\
\text { Puerto Rico } \\
\text { - The following statement is } \\
\text { required: 'Caution: New Drug } \\
\text { Limited by Federal (or US) law to } \\
\text { investigational use. }\end{array}$ & $\begin{array}{l}\text { - Label must be in English. } \\
18 \text { of the Medicines (Clinical Trials) } \\
\text { Regulations and section 4.6.3 of SGGCP }\end{array}$ \\
\hline $\begin{array}{l}\text { Protection of } \\
\text { trial subjects }\end{array}$ & $\begin{array}{l}\text { - Minimal detail on ICF requirements } \\
\text { - No incentive/financial inducements } \\
\text { are permitted for minors and } \\
\text { incapacitated adults } \\
\text { - Insurance information may be required } \\
\text { - No provisions for emergency consent }\end{array}$ & $\begin{array}{l}\text { - Detailed list of ICF requirements } \\
\text { Disclosure of anticipated pro-rated } \\
\text { payment for participation } \\
\text { - No requirement for insurance } \\
\text { information on ICF } \\
\text { - Provisions for emergency consent }\end{array}$ & $\begin{array}{l}\text { - Detailed list of ICF requirements } \\
\text { - Disclosure of anticipated pro-rated } \\
\text { payment for participation } \\
\text { - No requirement for insurance } \\
\text { information on ICF } \\
\text { - Provisions for emergency consent }\end{array}$ \\
\hline $\begin{array}{l}\text { Essential } \\
\text { document } \\
\text { retention }\end{array}$ & $\begin{array}{l}\text { - Essential documentation includes } \\
\text { CRF without medical records } \geq \\
5 \text { years } \\
\text { - If data is used to support a marketing } \\
\text { application, records must be } \\
\text { kept } \geq 15 \text { years } \\
\text { Record retention is } \geq 2 \text { years after } \\
\text { the last marketing authorisation } \\
\text { granted in the EU, or after } \\
\text { formal discontinuation of clinical } \\
\text { development of the IMP }\end{array}$ & $\begin{array}{l}\text { IMP batch records retention is } \\
\geq 5 \text { years after completion of } \\
\text { the clinical trial }(\mathrm{CT}) \text { or formal } \\
\text { discontinuation of the last study in } \\
\text { which the batch was used } \\
\text { - Sufficient samples of the IMP and } \\
\text { key packaging components must be } \\
\text { kept for } \geq 2 \text { years after completion } \\
\text { or formal discontinuation } \\
\text { - Record retention is } 2 \text { years after } \\
\text { marketing application is approved. }\end{array}$ & $\begin{array}{l}\text { Holder of CTC should ensure that } \\
\text { records are kept at least for whichever } \\
\text { of the following periods expires later: } \\
\text { - (a) until no pending or contemplated } \\
\text { marketing applications of the test material } \\
\text { in Singapore; (b) } 2 \text { years after the last } \\
\text { approval of a marketing application for the } \\
\text { test material in Singapore; (c) where the } \\
\text { clinical trial is discontinued, } 2 \text { years after } \\
\text { the licensing authority has been informed } \\
\text { of the discontinuation of the clinical trial } \\
\text { under regulation } 9 \text {; (d) } 6 \text { years after the } \\
\text { completion of the clinical trial; or (e) such } \\
\text { other period as the licensing authority } \\
\text { may direct }\end{array}$ \\
\hline $\begin{array}{l}\text { Legal } \\
\text { framework }\end{array}$ & $\begin{array}{l}\text { - European Union EU directives } \\
\text { applicable to all members } \\
\text { - National Laws apply } \\
\text { - Legal representative required } \\
\text { - Breach results in a fine or } \\
\text { imprisonment }\end{array}$ & $\begin{array}{l}\text { - US Federal statutes and regulations } \\
\text { are applicable to all } 50 \text { states } \\
\text { - Individual state laws apply } \\
\text { - Authorised representative required } \\
\text { - Breach results in debarment }\end{array}$ & $\begin{array}{l}\text { - Medicines Act and governed by the } \\
\text { Medicines (Clinical Trial) Regulations } \\
\text { - SGGCP follows the model of ICH GCP } \\
\text { - Statutory duty for all trials to comply } \\
\text { with SGGCP } \\
\text { - Breach results in a fine or imprisonment }\end{array}$ \\
\hline $\begin{array}{l}\text { Conduct of } \\
\text { clinical trial }\end{array}$ & $\begin{array}{l}\text { - PI statement not required by member } \\
\text { states } \\
\text { - Protocol amendment implementation } \\
\text { varies on classification, } \\
\text { i.e., substantial vs. non-substantial }\end{array}$ & $\begin{array}{l}\text { US Form FDA } 1572 \text { required to be } \\
\text { signed by the PI } \\
\text { Protocol amendments may be } \\
\text { implemented once received by } \\
\text { the FDA and protocol waivers } \\
\text { may be accepted under certain } \\
\text { circumstances }\end{array}$ & $\begin{array}{l}\text { - Protocol and consent forms should be } \\
\text { submitted for regulatory approval } \\
\text { - Revised clinical trial protocols and ICFs } \\
\text { do not need to be submitted if change is } \\
\text { logistical or administrative, e.g., change } \\
\text { of contact information, unless it involves } \\
\text { a change in sponsor, etc. } \\
\text { - Protocol waivers are discouraged }\end{array}$ \\
\hline
\end{tabular}

CA: competent authority; CRF: case report form; CTA: clinical trial authorisation; CTC: clinical trial certificate; EC: ethics committee; EU: European Union; FDA: Food and Drug Administration; HSA: Health Sciences Authority; ICF: informed consent form; ICH: International Conference on Harmonisation; IMP: investigational medicinal product; IND: investigational new drug; MS: member state; NIMP: non-investigational medicinal product; PI: principle investigator; SGGCP: Singapore guideline for good clinical practice; US: United State 


\section{CONCLUSION}

$\mathrm{CHI}$ studies, which are becoming increasingly commonplace, are an efficient research platform for many purposes. ${ }^{(1)}$ While the regulatory and ethical framework differs between countries, $\mathrm{CHI}$ studies are being performed in a carefully controlled and monitored environment such that this platform is a safe and cost-effective way of increasing our knowledge of infections and developing new vaccines and therapeutics. Singapore has the potential to develop this platform, as our regulatory requirements closely mirror that of the UK and the ethical framework is already in place.

\section{REFERENCES}

1. Pollard AJ, Savulescu J, Oxford J, et al. Human microbial challenge: the ultimate animal model. Lancet Infect Dis 2012; 12:903-5.

2. Riedel S. Edward Jenner and the history of smallpox and vaccination. Proc (Bayl Univ Med Cent) 2005; 18:21-5.

3. Clinical trials: Steps in malaria vaccine development. In: Malaria Vaccine Initiative [online]. Available in: http://www.malariavaccine.org/rd-clinical-trials.php. Accessed August 25, 2014.

4. Lillie PJ, Berthoud TK, Powell TJ, et al. Preliminary assessment of the efficacy of a T-cell-based influenza vaccine, MVA-NP+M1, in humans. Clin Infect Dis 2012; 55:19-25.

5. Youngner JS, Treanor JJ, Betts RF, Whitaker-Dowling P. Effect of simultaneous administration of cold-adapted and wild-type influenza A viruses on experimental wild-type influenza infection in humans. J Clin Microbiol 1994; 32:750-4.

6. Jones S, Evans K, McElwaine-Johnn $\mathrm{H}$, et al. DNA vaccination protects against an influenza challenge in a double-blind randomised placebo-controlled phase $1 \mathrm{~b}$ clinical trial. Vaccine 2009; 27:2506-12.

7. Hayden FG, Jennings $L$, Robson R, et al. Oral oseltamivir in human experimental influenza B infection. Antivir Ther 2000; 5:205-13.

8. Wilkinson TM, Li CK, Chui CS, et al. Preexisting influenza-specific CD4+ T cells correlate with disease protection against influenza challenge in humans. Nat Med 2012; 18:274-80

9. Treanor JJ, Kotloff K, Betts RF, et al. Evaluation of trivalent, live, cold-adapted (CAIV-T and inactivated (TIV) influenza vaccines in prevention of virus infection and illnes following challenge of adults with wild-type influenza $A(H 1 N 1), A(H 3 N 2)$, and B viruses. Vaccine 1999; 18:899-906.

10. Hayden FG, Fritz R, Lobo MC, et al. Local and systemic cytokine responses during experimental human influenza A virus infection. Relation to symptom formation and host defense. J Clin Invest 1998; 101:643-9.

11. Zaas AK, Chen M, Varkey J, et al. Gene expression signatures diagnose influenza and other symptomatic respiratory viral infections in humans. Cell Host Microbe 2009; 6:207-17.

12. Verhage DF, Telgt DS, Bousema JT, et al. Clinical outcome of experimental human malaria induced by Plasmodium falciparum-infected mosquitoes. Neth J Med 2005 63:52-8.

13. Thompson FM, Porter DW, Okitsu SL, et al. Evidence of blood stage efficacy with a virosomal malaria vaccine in a phase Ila clinical trial. PLoS One 2008; 3:e1493.

14. Webster DP, Dunachie S, Vuola JM, et al. Enhanced T cell-mediated protection against malaria in human challenges by using the recombinant poxviruses FP9 and modified vaccinia virus Ankara. Proc Natl Acad Sci U S A 2005; 102:4836-41.

15. Kester KE, Cummings JF, Ofori-Anyinam O, et al. Randomized, double-blind, phase 2a trial of falciparum malaria vaccines RTS,S/AS01B and RTS,S/AS02A in malaria-naive adults: safety, efficacy, and immunologic associates of protection. J Infect Dis 2009; 200:337-46.

16. Porter DW, Thompson FM, Berthoud TK, et al. A human Phase I//la malaria challenge trial of a polyprotein malaria vaccine. Vaccine $2011 ; 29: 7514-22$.

17. DeVincenzo J, Lambkin-Williams R, Wilkinson T, et al. A randomized, double-blind, placebo-controlled study of an RNAi-based therapy directed against respiratory syncytial virus. Proc Natl Acad Sci U S A 2010; 107:8800-5.

18. DeVincenzo JP, Wilkinson T, Vaishnaw A, et al. Viral load drives disease in humans experimentally infected with respiratory syncytial virus. Am J Respir Crit Care Med 2010; 182:1305-14

19. Gunther VJ, Putnak R, Eckels KH, et al. A human challenge model for dengue infection reveals a possible protective role for sustained interferon gamma levels during the acute phase of illness. Vaccine 2011; 29:3895-904.

20. Statler J, Mammen M, Lyons A, Sun W. Sonographic findings of healthy volunteers infected with dengue virus. J Clin Ultrasound 2008; 36:413-7.

21. Sun W, Eckels KH, Putnak JR, et al. Experimental dengue virus challenge of human subjects previously vaccinated with live attenuated tetravalent dengue vaccines. J Infect Dis 2013; 207:700-8.

22. Atmar RL, Bernstein DI, Harro CD, et al. Norovirus vaccine against experimental human Norwalk Virus illness. N Engl J Med 2011; 365:2178-87.

23. Atmar RL, Opekun AR, Gilger MA, et al. Norwalk virus shedding after experimental human infection. Emerg Infect Dis 2008; 14:1553-7.

24. García L, Jidy MD, García H, et al. The vaccine candidate Vibrio cholerae 638 is protective against cholera in healthy volunteers. Infect Immun 2005; 73:3018-24.

25. Glickman SW, McHutchison JG, Peterson ED, et al. Ethical and scientific implications of the globalization of clinical research. N Engl J Med 2009; 360:816-23.

26. [No authors listed]. Medical Ethics: The Japanese Version: Unit 731. In: Psychiatry, It's A Killing [online]. Available at: http://psychroaches.blogspot.sg/2009/07/medicalethics-japanese-version-unit.html. Accessed June 5, 2014.

27. Hornblum AM. They were cheap and available: prisoners as research subjects in twentieth century America. BMJ 1997; 315:1437-41.

28. Chernin E. Richard Pearson Strong and the iatrogenic plague disaster in Bilibid Prison, Manila, 1906. Rev Infect Dis 1989; 11:996-1004.

29. Shuster E. Fifty years later: the significance of the Nuremberg Code. N Engl J Med 1997; 337:1436-40.

30. World Medical Association Declaration of Helsinki. Ethical Principles for Medical Research Involving Human Subjects [online]. Available at: http://www.wma.net/ en/30publications/10policies/b3/17c.pdf. Accessed June 52014.

31. Vijayananthan A, Nawawi O. The importance of Good Clinical Practice guidelines and its role in clinical trials. Biomed Imaging Interv J 2008; 4:e5.

32. Miller FG, Grady C. The ethical challenge of infection-inducing challenge experiments. Clin Infect Dis 2001; 33:1028-33.

33. Lynch HF. The rights and wrongs of intentional exposure research: contextualising the Guatemala STD inoculation study. J Med Ethics 2012; 38:513-5.

34. Hope T, McMillan J. Challenge studies of human volunteers: ethical issues. J Med Ethics 2004; 30:110-6.

35. The Academy of Medical Sciences. Microbial Challenge Studies of Human Volunteers. A guidance document from the Academy of Medical Science [online]. Available at: http://www.acmedsci.ac.uk/viewFile/publicationDownloads/1127728424.pdf. Accessed November 5, 2013.

36. European Medicines Agency. Committee for Human Medicinal Products (CHMP). Note for Guidance on the Clinical Evaluation of Vaccines. 17 May 2005 [online]. Available at http://www.ema.europa.eu/docs/en_GB/document_library/Scientific_ guideline/2009/09/WC500003875.pdf. Accessed November 5, 2013.

37. US Department of Health and Human Services, Food and Drug Administration, Center for Drug Evaluation and Research (CDER), Center for Biologics Evaluation and Research (CBER), Center for Food Safety and Applied Nutrition (CFSAN). Guidance for Clinical Investigators, Sponsors, and IRBS. Investigational New Drug Applications (INDs)- Determining Whether Human Research Studies Can Be Conducted Without an IND [online]. Available at: http://www.fda.gov/downloads/Drugs/Guidances/ UCM229175.pdf. Accessed October 7, 2013.

38. European Medicines Agency. ICH Topic E 6 (R1) Guidance for Good Clinical Practice. Note for Guidance on Good Clinical Practice. CPMP//CH/135/95). Step 5 [online]. Available at: http://www.edctp.org/fileadmin/documents/EMEA_ICHGCP_Guidelines_July_2002.pdf. Accessed November 5, 2013.

39. Burgess LJ, Pretorius D. FDA abandons the Declaration of Helsinki: The effect on the ethical aspects of clinical trial conduct in South Africa and other developing countries. S Afr J Bioethics Law 2012; 5:87-90.

40. World Medical Association. WMA Published its Revised Declaration of Helsinki [online]. Available at: http://www.wma.net/en/40news/20archives/2013/2013_28//. Accessed June 4, 2014

41. TMQA. TMQA Regulatory News Update - July 2014 [online]. Available at: www. tmqa.co.uk/Pages/regulatory_news_1407.html. Accessed September 8, 2014.

42. Health Sciences Authority. Clinical Drug Trials in Singapore [online]. Available at: http://www.hsa.gov.sg/content/hsa/en/Health_Products_Regulation/Clinical_Trials/ Overview.html. Accessed August 25, 2014.

43. US Department of Health and Human Services, Food and Drug Administration, Center for Biologics Evaluation and Research. Guidance for Industry. Characterization and Qualification of Cell Substrates and Other Biological Materials Used in the Production of Viral Vaccines for Infectious Disease Indications [online]. Available at: http://www.fda. gov/downloads/biologicsbloodvaccines/guidancecomplianceregulatoryinformation/ guidances/vaccines/ucm202439.pdf. Accessed October 7, 2013.

44. European Commission Health and Consumers Directorate-General. The Rules Governing Medical Products in the European Union Volume 10 - Guidance Documents Applying to Clinical Trials. Guidance on Investigational Medicinal Products (IMPs) and 'Non Investigational Medicinal Products' (NIMPs)(Rev, 1 March 2011) [online]. Available at: http://ec.europa.eu/health/files/eudralex/vol-10/imp_032011.pdf. Accessed October 7, 2013.

45. European Commission Enterprise Directorate-General. Working Party on Control of Medicines and Inspections. Final Version of Annex 16 to the EU Guide to Good Manufacturing Practice. Certification by a Qualified Person and Batch Release [online]. Available at: http://ec.europa.eu/health/files/eudralex/vol-4/pdfs-m/v4_an16_200408_ en.pdf. Accessed November 7, 2013.

46. US Department of Health and Human Services, Food and Drug Administration, Center for Drug Evaluation and Research (CDER). Guidance for Industry Influenza: Developing Drugs for Treatment and/or Prophylaxis [online]. Available at: http://www. fda.gov/downloads/Drugs/GuidanceComplianceRegulatorylnformation/Guidances/ ucm091219.pdf. Accessed November 7, 2013

47. Singapore Guideline for Good Clinical Practice (SGGCP). Adapted from the $\mathrm{ICH}$ Harmonised Tripartite Guideline E6: Note for Guidance on Good Clinical Practice (CPMP/ICH/135/95)[online]. Available at: file:///C:/Users/Faizzah/Downloads/ SG_Good_Clinical_Practice_Oct_1999.pdf. Accessed November 5, 2013.

48. Fenty A. Clinical Trial Requirements. Similarities and Differences US vs. EU [online]. Available at: http://www.slideshare.net/RETIRE/clinical-trial-requirements-us-vs-eusimilarities-and-differences?utm_source=slideshow03\&utm_medium=ssemail\&utm _ campaign=share_slideshow_loggedout. Accessed October 10, 2013. 